\title{
Relationship between Starch and Amino Acid Levels of Broiler Diets on Growth Performance and Feed Efficiency
}

\section{NA Hartono ${ }^{1 *}$, Nahrowi ${ }^{2}$ and Sumiati ${ }^{2}$}

${ }^{1}$ Student, Post Graduate School, Bogor Agricultural University, Indonesia

${ }^{2}$ Nutrition and Feed Science, Animal Husbandry Faculty, Indonesia

\begin{abstract}
This study was conducted to investigate the relationship between starch and amino acid levels of broiler diets on growth performance and feed efficiency. In this study, 240 one-day old chicks were distributed to 6 treatments using a completely randomized design (CRD) with four replications. Three treatments were fed with high starch and three others were fed with low starch. Both type of diets were formulated as isocaloric with three levels of total lysine, varying from $1.34 \%, 1.43 \%, 1.48 \%$ for starter period ( $0-18$ days) and $1.18 \%, 1.3 \%, 1.35 \%$ for finisher period $(19-35$ days). The result showed that high starch level increased body weight gain $(p<0.01)$ and feed intake at 35 days $(p$ $<0.05$ ). Feed conversion ratio was better for the birds were fed a high starch level diet (1.66) compare with the low starch level (1.71). No interaction between starch level and amino acid level was observed for body weight gain feed intake and feed conversion ratio at 35 days. No differences for blood parameter glucose, uric acid and insulin. Significant interaction between starch level and amino acid was observed for uric acid. It was concluded that feeding high starch level based on corn soya diet increased body weight gain and feed intake. Starch level has relationship with blood glucose, insulin and utilization of protein and energy in broiler.
\end{abstract}

Keywords: Starch; Amino acid; Broiler performance

\section{Introduction}

Feed efficiency aims to achieve production results that match genetic potential with low feed costs and reduce the potential environmental pollution caused by excess nutrients which are not digested by livestock, especially proteins. One technique to improve feed efficiency is to use the concept of balance energy and protein in broiler feed formulation. In addition, protein is composed of amino acids with a certain ratio of the amino acid lysine (ideal protein concept model). Starch is a part of carbohydrate as important energy source for broiler chickens. The amount of starch is still not taken into account in predicting the energy content of a material. Starch provides a more than $50 \%$ of energy requirement in broiler feed which based on corn and soybean meal. Is generally assumed to be very high starch digestibility close to $100 \%$, but the rate of degradation in the intestine varies [1].

Feed with the starch content gradually broken down in the small intestine, will provide continuous glucose into the bloodstream. Glucose in the blood will be responded by the release of the hormone insulin. Insulin plays an important role in the transport of glucose and protein into muscle deposition during growth [2]. Continuous availability of glucose to the posterior part of the small intestine could prevent the use of amino acids as an energy source for the intestinal wall [3].

This study focused on investigate concept of balance energyamino acid related to the difference in the speed of starch digestibility in the small intestine Availability of different amounts of starch in the isocaloric feed in intestine, is expected to give different growth responses in broilers.

\section{Materials and Methods}

\section{Animal and Housing}

In this study, 240 birds (DOC) placed in to 24 pens. Six types of feed with four replication each replication contained 10 birds. Age 0-18 days use the same feed that kind of starter feed. Age 19-35 days used grower feed.

\section{Diets}

There are 6 types of feed formulations were used, which are 2 of the content of starch (high starch $36 \%$ and lower starch 32\%), which combined with 3 levels of the amino acid Lysine-based Total 1.34\%, $1: 43 \%, 1: 48 \%$ for the starter phase, and $1.18 \%, 1.3 \%, 1.35 \%$ for the grower phase. Other amino acids will follow the ratio of the total Lysine according to nutrient requirement ROSS 308. Prediction systems for nutrient content of raw materials using SFR (Schothorst Feed Research) system with Format International Formulation Software from England.

The feed is given in the form of crumble, with a minimum temperature of $80^{\circ} \mathrm{C}$ conditioner, die size of $3.2 \mathrm{~mm}$, minimum $90 \%$ PDI. Composition and nutrient content of research feed as in Tables 1 and 2 .

\section{Feed quality and blood parameters analysis}

- Proximate analysis: Quality feed were analyzed using full proximate AOAC method (1980).

- Blood parameters: Blood glucose levels (Glucose Hexokinase Kit, Bayer, USA), levels of the hormone insulin (Coat-A-Kits COUNTA Insulin, DPC, LA, CA) and blood uric acid (Biosystems kit), be read with a spectrophotometer.

- Starch Analysis: Polarimeter methods read with a spectrophotometer

*Corresponding author: NA Hartono, Student, Post Graduate School, Bogor Agricultural University, Indonesia, Tel: 62254400660, 62254400659; E-mail: mailto:nugrohoadi@cj.co.id

Received September 27, 2013; Accepted February 19, 2014; Published February 21, 2014

Citation: Hartono NA, Nahrowi, Sumiati (2014) Relationship between Starch and Amino Acid Levels of Broiler Diets on Growth Performance and Feed Efficiency. J Veterinar Sci Technol 5: 160. doi:10.4172/2157-7579.1000160

Copyright: (c) 2014 Hartono NA, et al. This is an open-access article distributed under the terms of the Creative Commons Attribution License, which permits unrestricted use, distribution, and reproduction in any medium, provided the original author and source are credited. 


\begin{tabular}{|c|c|c|c|c|c|c|}
\hline \multirow{2}{*}{ Raw Material } & \multicolumn{6}{|c|}{ Treatment } \\
\hline & Ro & R1 & R2 & R3 & R4 & R5 \\
\hline Corn & 57.118 & 57.449 & 58.671 & 46.497 & 46.075 & 47.468 \\
\hline Ricebran & 3.502 & 2.838 & 0.000 & 13.809 & 15.000 & 11.321 \\
\hline Soybean meal $47 \%$ & 27.764 & 26.970 & 27.792 & 26.966 & 24.757 & 27.445 \\
\hline Fish meal $60 \%$ & 5.000 & 5.000 & 5.000 & 5.000 & 5.000 & 5.000 \\
\hline Crude Palm Oil & 756 & 3.331 & 3.195 & 5.000 & 4.508 & 4.638 \\
\hline Meat Bone Meal $50 \%$ & 0.000 & 2.300 & 3.400 & 0.000 & 1.050 & 2.050 \\
\hline Poultry Meat Meal & 0.000 & 0.000 & 0.000 & 0.000 & 1.400 & 0.000 \\
\hline L-Lysine $78 \%$ & 0.195 & 0.270 & 0.285 & 0.190 & 0.290 & 0.300 \\
\hline L-Threonine 95\% & 0.062 & 0.113 & 0.122 & 0.063 & 0.105 & 0.112 \\
\hline DL-methionine 99\% & 0.294 & 0.353 & 0.370 & 0.288 & 0.352 & 0.370 \\
\hline Tryptopan $100 \%$ & 0.000 & 0.000 & 0.003 & 0.000 & 0.000 & 0.000 \\
\hline Limestone Ca $38 \%$ & 0.400 & 0.000 & 0.000 & 0.500 & 0.200 & 0.000 \\
\hline Dicalcium Phosphate 18\% & 1.250 & 0.827 & 0.629 & 1.120 & 0.723 & 0.748 \\
\hline Salt $\mathrm{NaCl}$ & 0.145 & 0.118 & 0.106 & 0.135 & 0.101 & 0.112 \\
\hline Mineral Premix & 0.100 & 0.100 & 0.100 & 0.100 & 0.100 & 0.100 \\
\hline Vitamin Premix & 0.100 & 0.100 & 0.100 & 0.100 & 0.100 & 0.100 \\
\hline Choline chloride & 0.100 & 0.100 & 0.100 & 0.101 & 0.101 & 0.096 \\
\hline Antimold propionic acid & 0.050 & 0.050 & 0.050 & 0.050 & 0.050 & 0.050 \\
\hline Antioxidant & 0.020 & 0.020 & 0.020 & 0.020 & 0.020 & 0.020 \\
\hline Anticoccydium & 0.060 & 0.060 & 0.060 & .060 & 0.060 & 0.060 \\
\hline \multicolumn{7}{|l|}{ Nutrient Content } \\
\hline Crude Protein ( & 21.34 & 22.17 & 22.88 & 1.04 & 22.00 & 22.60 \\
\hline ME (Kkal/kg & 3100.0 & 3100.8 & 3100.1 & 3100.2 & 3100.6 & 3100.0 \\
\hline $\mathrm{Ca}(\%)$ & 0.95 & 0.95 & 1.04 & 0.95 & 0.95 & 0.91 \\
\hline $\mathrm{P}(\%)$ & 0.75 & 0.79 & 0.78 & 0.86 & 0.89 & 0.87 \\
\hline Crude Fiber (\% & 2.51 & 2.46 & 2.25 & 3.29 & 3.37 & 3.12 \\
\hline Crude Fat (\%) & 7.55 & 7.26 & 6.94 & 9.60 & 9.47 & 9.19 \\
\hline Starch (\%) & 36.00 & 35.98 & 36.01 & 32.09 & 32.13 & 32.05 \\
\hline Lysine (\%) & 1.34 & 1.43 & 1.48 & 1.34 & 1.43 & 1.48 \\
\hline $\mathrm{Cl}(\%)$ & 0.278 & 0.289 & 0.29 & 0.284 & 0.284 & 0.286 \\
\hline $\mathrm{Na}(\%)$ & 0.16 & 0.16 & 0.16 & 0.16 & 0.16 & 0.16 \\
\hline Methio & 0.664 & 0.732 & 0.757 & 0.661 & 0.732 & 0.755 \\
\hline Methionine + Cystine ( & 1.00 & 1.07 & 1.11 & 1.00 & 1.07 & 1.11 \\
\hline
\end{tabular}

R0: starch $36 \%$ - lysine $1.34 \%$, R1: starch $36 \%$ - lysine $1.43 \%$, R2 : starch $36 \%$ lysine $1.48 \%$, R3: starch $32 \%$-lysine $1.34 \%$, R4 : starch $32 \%$ - lysine $1.43 \%$, R5: starch $32 \%$ - lysine $1.48 \%$

Table 1: Composition and nutrient content of pre starter feed (0-18 days).

\section{Starch and protein digestibility}

- Ileal Starch Digestibility (\%): calculated by subtracting the total amount of starch consumed with remaining starch in the small intestine digesta, divided by the total starch consumed multiplied by $100 \%$.

- Total protein digestibility (\%): calculated by subtracting the total protein consumed by the amount of protein remaining in the feces, divided by the total protein consumed multiplied by $100 \%$.

\section{Chicken growth}

- Feed intake (g/bird): measured by weighing the amount of feed consumed during the study.

- Average weight gain (g/bird): calculated by calculating the weight by the end of the study reduced the initial weight.

- Feed Conversion Ratio: calculated by comparing feed consumption with weight gain.

\section{Statistical Analysis}

The experimental design used in this study is completely randomized design (CRD) with 4 replications $2 \times 3$ factorial. The data obtained were analyzed using analysis of variance (ANOVA), the differences among mean treatments were analyzed using Tukey test [4].

\section{Results and Discussion}

\section{Weight gain}

Based on Table 3, the average weight gain of birds aged 0-35 days in all treatments ranged from 1659.82-1891.54 gram. Potential genetic of modern broiler strain ROSS for weight gain in 35 days old is 1979 gram. Best result in this study was $95.5 \%$ of genetic potential.

Different starch content in feed between $36 \%$ and $32 \%$ gave a significant influence on the weight of the chicken $0-35$ days $(\mathrm{P}<0.01)$. Weight gain was not influenced by difference levels of amino acids. The results showed no interaction between level of starch and amino acids on chicken weight gain. Feed with starch content of $36 \%$ led to

\begin{tabular}{|c|c|c|c|c|c|c|}
\hline \multirow{2}{*}{ Raw Material } & \multicolumn{6}{|c|}{ Treatment } \\
\hline & Ro & R1 & R2 & R3 & $\mathrm{R} 4$ & R5 \\
\hline Corn & 59.021 & 54.482 & 55.154 & 45.787 & 45.799 & 44.655 \\
\hline Ricebran & 10.000 & 10.000 & 407 & 15.000 & 15.000 & 15.000 \\
\hline Soybean meal 4 & 18.962 & 22.121 & 21.513 & 17.836 & 17.195 & 16.178 \\
\hline Fish meal $60 \%$ & 5.000 & 5.000 & 5.000 & 5.000 & 5.000 & 5.000 \\
\hline Crude Palm Oil & 3.226 & 4.024 & 3.753 & 5.000 & 5.000 & 6.000 \\
\hline Meat Bone Meal $50^{\circ}$ & 1.600 & 2.300 & 4.450 & 0.450 & 4.600 & 2.400 \\
\hline Poultry Meat Meal & 0.000 & 0.000 & 0.000 & 4.500 & 1.050 & 0.000 \\
\hline L-Lysine $78 \%$ & 0.220 & 0.245 & 0.275 & 0.235 & 0.335 & 0.240 \\
\hline L-Threonine $95 \%$ & 0.085 & 0.110 & 0.123 & 0.088 & 0.140 & 0.088 \\
\hline DL-methionine $99 \%$ & 0.285 & 0.341 & 0.362 & 0.328 & 0.368 & 0.283 \\
\hline Wheat Pollard & 0.000 & 0.000 & 0.000 & 0.000 & 0.000 & 4.050 \\
\hline Copra Expeller & 0.000 & 0.000 & 0.000 & 5.000 & 5.000 & 5.000 \\
\hline Dicalcium Phospr & 1.014 & 0.816 & 0.428 & 0.265 & 0.000 & 0.541 \\
\hline Salt $\mathrm{NaCl}$ & 0.121 & 0.111 & 0.086 & 0.062 & 0.063 & 0.104 \\
\hline Mineral Premix & 0.100 & 0.100 & 0.100 & 0.100 & 0.100 & 0.100 \\
\hline Vitamin Premix & 0.100 & 0.100 & 0.100 & 0.100 & 0.100 & 0.100 \\
\hline Choline chloride $60 \%$ & 0.136 & 0.120 & 0.119 & 0.119 & 0.120 & 0.130 \\
\hline Antimold propionic a & 0.050 & 0.050 & 0.050 & 0.050 & 0.050 & 0.050 \\
\hline Antioxidant & 0.020 & 0.020 & 0.020 & 0.020 & 0.020 & 0.020 \\
\hline Anticoccydium & 0.060 & 0.060 & 0.060 & 0.060 & .060 & 0.060 \\
\hline \multicolumn{7}{|l|}{ Nutrient Content } \\
\hline Crude Protein (\%) & 18.949 & 20.509 & 21.182 & 21.262 & 21.072 & 19.205 \\
\hline ME (Kkal/kg) & 3200.7 & 3200.9 & 3200.0 & 3200.8 & 3200.8 & 3200.6 \\
\hline $\mathrm{Ca}(\%)$ & 0.90 & 0.94 & 1.09 & 0.87 & 1.06 & 0.88 \\
\hline $\mathrm{P}(\%)$ & 0.84 & 0.85 & 0.88 & 0.84 & 0.91 & 0.89 \\
\hline Crude Fiber (\%) & 2.90 & 2.93 & 2.80 & 3.78 & 3.74 & 4.01 \\
\hline Crude Fat (\%) & 7.95 & 8.60 & 8.40 & 10.74 & 10.79 & 11.54 \\
\hline Starch (\%) & 36.77 & 36.00 & 36.00 & 31.98 & 31.99 & 32.02 \\
\hline Lysine (\%) & 1.18 & 1.30 & 1.35 & 1.18 & 1.30 & 1.35 \\
\hline $\mathrm{Cl}(\%)$ & 0.284 & 0.284 & 0.286 & 0.26 & 0.284 & 0.27 \\
\hline $\mathrm{Na}(\%)$ & 0.16 & 0.16 & 0.16 & 0.16 & 0.16 & 0.16 \\
\hline Methionine (\%) & 0.629 & 0.702 & 0.730 & 0.701 & 0.735 & 0.629 \\
\hline Methionine + Cystine (\%) & 0.930 & 1.020 & 1.050 & 1.024 & 1.05 & 0.931 \\
\hline
\end{tabular}

R0: starch 36\% -lysine 1.18\%, R1:starch 36\% - lysine 1.3\%, R2:starch 36\%- lysine $1.35 \%$, R3: starch $32 \%$ - Iysine 1.18\%, R4: starch $32 \%$-lysine 1.3\%, R5:starch -lysine $1.35 \%$

Table 2: Composition and nutrient content of starter feed (19-35 days). 


\begin{tabular}{|c|c|c|c|c|c|c|}
\hline Item & Ro & $\mathrm{R} 1$ & $\mathrm{R} 2$ & R3 & $\mathrm{R} 4$ & R5 \\
\hline Gain (g/bird) & $1891.54 \pm 110.18^{a}$ & $1795.36 \pm 41.37^{\mathrm{a}}$ & $1811.02 \pm 143.30^{a}$ & $1659.30 \pm 90.93^{b}$ & $1665.82 \pm 99.48^{b}$ & $1676.43 \pm 96.65^{b}$ \\
\hline Consumption (g/bird) & $3199.32 \pm 99.06^{a}$ & $2971.80 \pm 144.8^{a}$ & $3003.95 \pm 295.25^{a}$ & $2829.07 \pm 60.98^{b}$ & $2795.76 \pm 128.3^{b}$ & $2931.84 \pm 70.02^{b}$ \\
\hline FCR & $1.69 \pm 0.1$ & $1.65 \pm 0.06$ & $1.657 \pm 0.11$ & $1.70 \pm 0.06$ & $1.68 \pm 0.03$ & $1.75 \pm 0.08$ \\
\hline
\end{tabular}

Means in the same row with different superscript differ significantly $(P<0.05)$.

R0: starch 36\%- lysine 1.34\%, R1: starch 36\%- lysine 1.43\%, R2 : starch 36\%-lysine 1.48\%, R3: starch 32\% -lysine 1.34\%, R4 : starch 32\% - lysine 1.43\%, R5: starch $32 \%$ - lysine $1.48 \%$

Table 3: Average weight gain, feed consumption and conversion ratio age 0-35 days.

\begin{tabular}{|c|c|c|c|c|c|c|}
\hline \multirow{2}{*}{ Item } & \multicolumn{5}{|c|}{ Treatment } \\
\cline { 2 - 6 } & R0 & R1 & R2 & R3 & R4 \\
\hline Protein Dig. & $68.98 \pm 2.93^{\mathrm{c}}$ & $74.36 \pm 4.24^{\mathrm{c}}$ & $82.70 \pm 2.49^{\mathrm{b}}$ & $77.70 \pm 5.13^{\mathrm{b}}$ & $81.68 \pm 5.7^{\mathrm{b}}$ & $84.22 \pm 2.26^{\mathrm{a}}$ \\
\hline Starch Dig. & $99.42 \pm 0.02^{\mathrm{a}}$ & $99.48 \pm 0.11^{\mathrm{a}}$ & $99.47 \pm 0.11^{\mathrm{a}}$ & $99.09 \pm 0.45^{\mathrm{b}}$ & $99.39 \pm 0.3^{\mathrm{b}}$ & $99.26 \pm 0.29^{\mathrm{b}}$ \\
\hline
\end{tabular}

Means in the same row with different superscript differ significantly $(P<0.05)$.

R0: starch 36\%- lysine 1.34\%, R1: starch 36\%- lysine 1.43\%, R2 : starch 36\%- lysine 1.48\%, R3: starch 32\% -lysine 1.34\%, R4 : starch 32\% - Iysine 1.43\%, R5: starch $32 \%$ - lysine $1.48 \%$

Table 4: Average intestine starch digestibility and total protein digestibility age 0-35 days

\begin{tabular}{|c|c|c|c|c|c|}
\hline \multirow{2}{*}{ Parameter } & \multicolumn{4}{|c|}{ Treatment } \\
\cline { 2 - 6 } & R0 & R1 & R2 & R3 & R4 \\
\hline Glukosa $(\mathrm{mg} / \mathrm{dL})$ & $223.68 \pm 14.17$ & $212.14 \pm 10.71$ & $209.09 \pm 16.90$ & $209.28 \pm 7.21$ & $209.22 \pm 19.31$ \\
\hline Uric Acid $(\mathrm{mg} / \mathrm{dL})$ & $2.32 \pm 0.02$ & $2.82 \pm 0.26$ & $3.02 \pm 0.11$ & $2.92 \pm 0.03$ & $2.87 \pm 0.18$ \\
\hline Insulin $(\mu \mathrm{l} / \mathrm{mL})$ & $2.52 \pm 0.25 \mathrm{a}$ & $2.16 \pm 0.18 \mathrm{c}$ & $2.72 \pm 0.20 \mathrm{a}$ & $2.39 \pm 0.20 \mathrm{~b}$ & $1.73 \pm 0.05 \mathrm{~d}$ \\
\hline
\end{tabular}

Means in the same row with different superscript differ significantly $(\mathrm{P}<0.05)$

R0: starch 36\%- lysine 1.34\%, R1: starch 36\%- lysine 1.43\%, R2 : starch 36\%- lysine $1.48 \%$, R3: starch $32 \%$-lysine $1.34 \%$, R4 : starch 32\% - lysine 1.43\%, R5: starch $32 \%$ - lysine $1.48 \%$

Tabel 5: Average Glucose, Uric Acid and Insulin in blood.

higher feed intake than the diet feed containing $32 \%$ of starch $(\mathrm{P}<0.05)$. Difference in feed intake is causing different starches consumption. Starch is part of energy source carbohydrate which is essential for broiler. Starch broke down into glucose in small intestines. Pancreatic $a$-amylase secreted into the lumen of the small intestine, especially in the jejunum to break the bonds $\alpha-1,4$ starch.

Glucose is absorbed through the small intestinal wall, through sodium and potassium pump mechanism. Glucose is needed as a precursor in the citric acid cycle (citric acid cycle). Oxidation of glucose produces energy which is necessary for the synthesis of glycogen, amino acids, fatty acids and other metabolites. Feed that containing $36 \%$ starch produces more glucose compared with the diet containing $32 \%$ starch. This evidenced by the digestibility of starch in the small intestine (ileal Digestibility starch) were significantly different $(\mathrm{P}<$ 0.05 ), ie $99.46 \%$ and $99.26 \%$ between diets with a high starch compared with lower starch diet. Glucose produced of feed containing different starches will be determined by the amount of starch entering the small intestine multiplied by it digestibility level.

Feed with adequate starch content, will provide continuous glucose into the bloodstream. Glucose in the blood will be responded by the release of the insulin hormone [5]. Insulin plays an important role in the transport of glucose and deposition protein into muscle during growth [2]. Black et al. [6] stated that the unequal rate of starch digestibility and protein affect protein deposition and broiler performance.

\section{Consumption and Feed Conversion Ratio}

Based on Table 3, the average feed consumption in chickens aged 0-35 days all treatments ranged from 2795.76 -3199.32 gram. Genetic potential of modern broiler strain ROSS for feed consumption to 35 days old is 3248 gram. Average feed intake in this study was $90.9 \%$ of genetic potential. Starch content in different feed between $36 \%$ and $32 \%$ gave significant effect on feed consumption of chicken 0-35 days age $(\mathrm{P}>0.05)$. Feed consumption is not influenced by differences in the levels of amino acids in the diet. The results showed there is no interaction between level of starch and amino acids on broiler feed consumption. Differences on starch content in the diet cause differences gelatinization process at the pellet-making process heating steam temperature above $80{ }^{\circ} \mathrm{C}$, leading to differences resistance pellet. Pellet quality was also influenced by the feed composition. A good quality pellet and not easily destroyed is one of the things that led to increased feed intake [1].

Feed conversion 0-35 day old chicks in all treatments ranged between 1.65-1.75. Genetic potential of modern broiler strain ROSS for feed conversion for age 35 days is 1.607 . Average feed conversion in this study was $95 \%$ of the genetic potential. Starch content in different feed between $36 \%$ and $32 \%$ had no real effect on $0-35$ days age chicken feed conversion $(\mathrm{P}<0.05)$. Feed conversion is not influenced by differences in the levels of amino acids in the diet. The results showed no interaction between level of starch and amino acids to the broiler feed conversion. Feed containing higher starch tends to provide a better feed conversion ration compared with lower starch content is 1.66 and 1.69 .

\section{Ileal starch digestibility}

Based on Table 4, the average digestibility of starch in the small intestine 35 days old chicken on all treatments ranged from 99.09 $99.48 \%$. Starch content in different feed between $36 \%$ and $32 \%$ gave significant effect on digestibility of starch in the small intestine of chicken $0-35$ days $(P<0: 05)$. Digestibility of starch in the small intestine is not influenced by differences in the levels of amino acids in the ration. The results showed no interaction between level of starch and level of amino acids for starch digestibility to the small intestine for 35 day old chickens. Feed containing higher starch provides a higher digestibility of starch in the intestine than the lower starch diet containing $(99.46 \%$ and $99.26 \%$ ).

\section{Total protein digestibility}

Based on Table 4, the average of total feed protein digestibility of 
chickens aged 35 days on all treatments ranged from $68.98-84.22 \%$. Starch content in different feed between $36 \%$ and $32 \%$ gave real effect on protein digestibility chicken feed $0-35(\mathrm{P}<0: 05)$. Protein digestibility is influenced by differences in the levels of amino acids in the diet $(\mathrm{P}$ $<0: 05)$. The results showed no interaction between level of starch and level of amino acids for protein digestibility. Feed containing higher starch gives a lower protein digestibility than the diet containing lower starch $(75.35 \%$ and $84.22 \%)$. Results of this study indicate that although feed with low starch content have higher protein digestibility, but did not give weight gain better than the feed that contain more starch. Selle et al. [7] states that the rate of absorption of amino acids associated with the rate of starch digestibility and absorption of glucose that had effect on the growth and deposition protein. Nitrogen Retention not correlated with the rate of nitrogen digestibility

\section{Content of Glucose, Uric Acid and Insulin in Chicken Blood}

Blood glucose levels ranged between $200.14 \mathrm{mg} / \mathrm{dl}-223.68 \mathrm{mg} /$ dl. Hazelwood [8] stated that the levels of glucose in broilers is higher compared with other mammals, the range $180-250 \mathrm{mg} / \mathrm{dL}$. Chickens in a state of hypoglycemia when blood glucose levels $137 \mathrm{mg} / \mathrm{dL}$ and hyperglicemia on blood glucose levels $363 \mathrm{mg} / \mathrm{dL}$ [9]. Results showed no significant differences in all treatments. Feed containing higher starch tend to have higher blood glucose levels compared with a diet containing a low starch content $(214.97 \mathrm{mg} / \mathrm{dL}$ and $206.21 \mathrm{mg} / \mathrm{dL})$. Blood glucose always regulated in relatively constant levels through glucoregulation mechanism which is controlled by several metabolic hormones such as insulin, glucagon, pancreatic polypeptide, corticosteron and thyroxin [9]. Levels of insulin in the blood of chickens significantly influenced by the levels of starch and amino acids in the diet $(p<0.05)$. Interaction between starch content and amino acids in the diet did not affect the levels of insulin. It showed that glucose results from breakdown of starch in diet stimulating secretion of insulin hormone by the pancreas [5]. Difference in starch content in feed will also result in different amounts of glucose. Grizard et al. [10] stated that insulin plays a role in protein deposition in the body. This is thought to cause better weight gain on diet containing more starch. Adding of the amino acid from Lysine $1: 34 \%$ to $1: 43 \%$ did not respond higher insulin levels, both on the high starch and lower starch diet. Uric acid level in the blood can be used as one indicator to the final result nitrogen metabolism Hartman et al. [11].

Donsbough et al. [12] stated levels of uric acid in broilers in the range of 2:02 mg/dL $-5: 13 \mathrm{mg} / \mathrm{dL}$. The result of this study shows that differences in the levels of starch and amino acids in the diet treatment did not affect the levels of uric acid in the chicken blood. The result of this study similar to that expressed by Donsbough et al. [12]. Levels of uric acid had a tendency to increase at each addition of acid amino. Xie et al. [13] suggest that increased levels of uric acid by the addition of amino acids methionine in diet. Uric acid as an antioxidant stated by Hare and Johnson [14], therefore its existence is also associated with a state of oxidative stress [15]. Uric acid levels increase when the nitrogen intake increased Hevia and Clifford [16].

\section{Conclusions}

Diet containing the same type starch but with different numbers gives different of weight gain and feed consumption in broilers ages 35 days. Feed containing high starch tends to have more levels of glucose and insulin in the blood. Total digestibility of proteins not directly describes the growth performance of chickens on feed which the starch content distinguished.

\section{Recommendations}

Broiler feed formulation needs to pay attention to the content of starch in the ration, because the process of starch digestion and glucose absorption associated with protein deposition.

\section{References}

1. Weurding RE, Veldman A, Veen WA, van der Aar PJ, Verstegen MW (2001) In vitro starch digestion correlates well with rate and extent of starch digestion in broiler chickens. J Nutr 131: 2336-2342

2. Fox SI (1996) Human Physiology page 588. Wm.C Brown Publishers, Dubugue

3. Weurding RE, Enting H, Verstegen MW (2003) The relation between starch digestion rate and amino acid level for broiler chickens. Poult Sci 82: 279-284

4. Steel RGD, Torrie JH (1995) Prinsip dan prosedur statistika : suatu pendekatan biometrik. Gramedia, Jakarta.

5. Henquin JC (2000) Triggering and amplifying pathways of regulation of insulin secretion by glucose. Diabetes 49: 1751-1760

6. Black JL, Hughes RJ, Nielsen SG, Tredrea AM, MacAlpine R, et al. (2005) Proceedings, Australian Poultry Science Symposium 16: 21-29

7. Selle PH, Liu SY, Cai J, Cowieson AJ (2012) Animal Production Science.

8. Hazelwood RL (1984) Pancreatic hormones, insulin/glucagon molar ratios, and somatostatin as determinants of avian carbohydrate metabolism. J Exp Zool 232: 647-652

9. Goodwin, Denise B, John B, Mc Murray L, William IR et al. (1994) Blood Glucose value and definitions of Hypoglicemia and Hyperglycemia. Georgia Poultry Laboratory. 38: 861-865

10. Grizard J, Picard B, Dardevet D, Rochon BMC (1999) Protein metabolism and Nutrition, EAAP Publication no 96.Wageningen Pers. Pp 184-187

11. Hartman S, Taleb SA, Geng T, Gyenai K, Guan X, et al. (2006) Comparison of plasma uric acid levels in five varieties of the domestic turkey, Meleagris gallopavo. Poult Sci 85: 1791-1794.

12. Donsbough AL, Powell S, Waguespack A, Bidner TD, Southern LL (2010) Uric acid, urea, and ammonia concentrations in serum and uric acid concentration in excreta as indicators of amino acid utilization in diets for broilers. Poult Sci 89: $287-294$

13. Xie M, Hou SS, Huang W, Zhao L, Yu JY, et al. (2004) Interrelationship between methionine and cystine of early Peking ducklings. Poult Sci 83: 1703-1708.

14. Hare JM, Johnson RJ (2003) Uric acid predicts clinical outcomes in heart failure: insights regarding the role of xanthine oxidase and uric acid in disease pathophysiology. Circulation 107: 1951-1953.

15. Cutler RG (1984) Urate and ascorbate: their possible roles as antioxidants in determining longevity of mammalian species. Arch Gerontol Geriatr 3: 321-348.

16. Hevia P, Clifford AJ (1977) Protein intake, uric acid metabolism and protein efficiency ratio in growing chicks. J Nutr 107: 959-964. 